\title{
Mass Transport of Nitrate in Soil by Utilizing the Optimized Diffusion Cell and Emission-Transmission-Immission Concept
}

\author{
Noor M. Al-Kharabsheh ${ }^{1 *}$, Rafig Azzam² \\ ${ }^{1}$ Department of Water Resources and Environmental Management, Al-Balqa Applied University, Al-Salt 19117, Jordan \\ ${ }^{2}$ Department of Engineering Geology and Hydrogeology, RWTH Aachen University, Aachen 52064, Germany
}

Received: 7 January 2018

Accepted: 3 July 2018

\begin{abstract}
Quantification methods of mass transport of contaminants such as nitrate into groundwater are still inefficient due to lack of knowledge about the parameters governing the transport process. Thus, in this research, a new methodology called optimized diffusion cell (ODC) setup was established to investigate nitrate input into groundwater through an unsaturated zone. This experimental modeling setup mimics the emission-transmission-immission (ETI) concept, which allows for quantification of input and output nitrate fluxes under realistic conditions. Three various nitrate concentrations were added to undisturbed soil samples of $1 \mathrm{~cm}$ thickness. The ODC setup was established to minimize the advective transport of nitrate in sandy soil samples due to high permeability. Outcomes revealed that a sorbed amount of nitrate was little due to advective transport compared to that carried out by diffusion. Additionally, for the whole analyzed soil samples of different soil classes, the amount of sorbed nitrate by advection did not exceed $1 \%$ of the total sorbed amount. On average, $30 \%$ of total nitrate mass input was sorbed. Results of the ODC setup prove its efficiency to simulate nitrate mass transport within the enclosed soil samples. Such findings can be used to predict endurable risk of nitrate transport to groundwater and to analyze sorption isotherms.
\end{abstract}

Keywords: advection, optimized diffusion cell, mass transport, input and output nitrate fluxes, sorption isotherms

\section{Introduction}

Nitrate pollution is a worldwide environmental concern [1]. Drastic increases of nitrate concentrations in groundwater resources in many countries may be

*e-mail:drnoormkh@gmail.com attributed to increasing trends in applying nitrogenous fertilizers or intensive agricultural practices, highdensity urbanization with unsewered sanitation and the use of sewage effluent for irrigation [2]. Nitrate can bypass the unsaturated zone and leach into groundwater system and thus might be subjected to different processes, such as sorption and denitrification [3]. The ability of soil to adsorb ions from aqueous solution has inevitable concomitant impacts on agricultural issues 
such as soil fertility and remediation of contaminated soil, and health concerns [4]. Therefore, understanding nitrate behavior as it travels through the unsaturated zone reaching the groundwater is critical for land use management, soil and groundwater protection and remediation. Nitrate transport processes such as retardation and adsorption could be thoroughly assessed.

Several previous studies attempted to investigate the nitrate transport from non-point source and its concomitant influence. The nitrogen transformation in soil involves major processes such as nitrogen fixation, ammonification, nitrification, immobilization and denitrification. Leaching of nitrate to the deeper layers and surface waters can be reduced by nitrate retention, either plant/microbial immobilization or by sorption onto the hydroxides of iron and aluminium [5].

Nitrate sorption capacity and its retardation in soils are affected by high $\mathrm{pH}$ [3]. Soil mineralogy and surface charge also affect anion sorption [6]. High anions such as chloride, phosphate and sulphate content in soil will also restrain nitrate sorption due to the competition of exchange sites [7]. Nitrate has high water solubility and low affinity to be adsorbed on the charged soil matrix, therefore it is vulnerable to be washed out of the soil system by percolating water. Thus, nitrate leaching after fertilization has the potential to pollute the underlying groundwater system [8]. The leaching rate was much higher in sandy soils and under overfertilization conditions [9]. Although several procedures are available for treating the nitrate-contaminated water, i.e., by reverse osmosis, electro-dialysis, anionexchange and biological denitrification, source control of nitrate leaching is the most excellent option for better environmental protection [10].

Different approaches have been applied to conceptualize solute transport in the subsurface system; these approaches have increased knowledge about key transport and transformation processes and parameters. Field approaches using stochastic modelling of incomprehensive descriptive solute transport mechanisms are generally applied where estimation of contaminant transport often ends by general parameterization [9]. There is an existing concern that laboratory-based experiments are not yet well enough to be explored especially for contaminants such as nitrate. The transport assessment of this anion in the subsurface system and into groundwater is complicated by a variety of parameters that may affect leaching. Therefore, several laboratory methods have been developed to estimate transport parameters of nitrate in the subsurface system [8]. Batch experiments and miscible displacement techniques are probably the most common methods to quantify nitrate transport in soil and to estimate sorption and retardation parameters. Batch techniques or equilibrium methods are applied to estimate nitrate transport parameters in soil. Through this kind of experiment, the solid is shaken in solute solution until the adsorption or desorption equilibrium is reached and the remaining solute concentration is measured. Adsorption of nitrate in different types of soils was measured and it was found to increase with depth [11]. Batch experiment on nitrate leaching in different soils displayed an increase in sorption with both depth and increased nitrate solution concentrations [12]. Limitations of batch techniques have been stated by Azzam and Lambarki [13]. These limitations include no simulation of the actual field conditions of the determination of maximum adsorption capacity in subsurface soil systems due to the breakdown of soil aggregates and solubilisation of soil components by sample agitation, differences in pore water solution composition and soil solution ratios that are much smaller than in natural soil systems. This often results in inappropriate assessments of concentration and composition of solution change during the equilibrium period [14]. Miscible displacement or flow-through technique is a continuous flow process in which solute solution flows through a soil column in one direction. The effluent from the soil column at different time intervals is collected and analysed to determine the sorption behaviour during time [15]. The results of the miscible displacement can be evaluated using different methods, where the breakthrough curve is the most popular. Parameters such as flow rate and soil properties will affect this approach. Advantages offered by this technique over the traditional batch method include simulating the field conditions considering certain soil-solution ratios without altering natural soil aggregates [16]. The effect of soil texture on nitrate sorption and leaching using miscible displacement experiments was investigated by Lee et al. [17]. It was concluded that soil texture has an influence on the pattern of nitrate removal. Undisturbed soil columns were studied to investigate nitrate adsorption using the miscible displacement experiments. It was found that positive relationships between retardation coefficient and the content of amorphous material with depth, and between the preferential flow in the soil columns with the mobility and velocity of nitrate moving through the columns [18].

Another series of practical miscible displacement laboratory setups were consequently applied on similar cell bodies with different setups and serious modifications. A diffusion cell setup for testing clay specimens was developed and the results confirmed that the analytical and semi-analytical solutions of the advection-dispersion equation can be potentially used to determine subsurface-released contamination [19]. The results of another miscible displacement called transmission cell setup pointed out that mass balance can be calculated for every virtual layer until the groundwater is reached in addition distributing the pollutant in the unsaturated zone and the amount of input on the groundwater can be obtained from the total mass balance as time-dependent [20]. Then an advection-diffusion cell setup was established to assess nitrate retardation in different soils and it was observed that the amount of nitrate sorbed in soil was dependent 
on the particle size distribution and the content of organic matter ranged from about $10 \%$ in sandy soil to about $60 \%$ in clayey soil. However, unfavourable small amounts of nitrate output flux for fine-textured soil samples were obtained due to the formation of microbial films over the surface layer of many soil samples inside the advection-diffusion cell. This difficulty led to underestimating the maximum sorption capacity of studied soils during certain sorption phases [21].

This study attempts to develop a practical miscible displacement laboratory setup called optimized diffusion cell (ODC). It is a modified form of the diffusion cell setup, utilizing it to meaningfully characterize nitrate transport in different soils along with focusing on hindering formation of thin layer of microbial film on top of soil samples in the former setup. Consequently, difficulties in inhibiting reaching the breakthrough point for the fine soil texture samples are not faced. Formation of the microbial film reduced the observations of output nitrate flux, therefore a sequent problem represented by hindering reaching the fine soil samples to the equilibrium condition was found by Aljazzar [22]. Therefore, the former researcher was obliged to assess sorption capacity and the retardation parameter of the fine texture soil samples using analytical solution of the mathematical equation (advective-dispersion equation) to investigate nitrate transport in his setup (advection diffusion cell setup) [22]. A major advantage of the optimized setup is represented by avoiding the over-mixing that occurs in the batch experiments. Furthermore, it allows an undisturbed soil sample to be imbedded within it, conserving most of the original physical soil characteristics that makes the sorption results of the ODC setup more reliable. The batch experiments show overestimation of sorption rate than ODC test - especially for samples with higher organic matter content [20]. On the other hand, sorption can be best fit by the infiltration rate inner and outer of the soil specimen within the diffusion cell. Additionally, the ODC setup is a general approach that can be applied for contaminants having similar characteristics to nitrate ions.

The most significant innovation of the current study's setup is switching off the effect of hydraulic head in order to enhance the nitrate sorption property by sandy soil. Furthermore, equipment is disinfected with $3 \%$ hydrogen peroxide, and cylinders of nitrate solutions are covered with aluminium foils to hinder microbial growth on the top surfaces of soil slices and algal growth. Moreover, undisturbed soil samples are collected and slices of $1 \mathrm{~cm}$ thickness are prepared to preserve the natural porosity and various soil properties. The certain thickness of the sample is determined to overcome the long-time experiment end point. More explanation about these modifications is clearly described in the materials and methods section.

The main objective of this study is to provide a modified laboratory setup to describe nitrate mass transport scenario and quantify sorption of various soil classes wherein a common procedure for the contaminant transport prognosis does not yet exist. Such quantification has important implications for the interpretation of nitrate mass-balance data and should possibly be integrated in nitrate simulation models. Subsequently, a major part of the knowledge required for groundwater protection against nitrate leaching or to evaluate its vulnerability is provided.

\section{Material and Methods}

The ODC setup is a general applicable approach for contaminants that have similar characteristics to nitrate ion.

\section{Emission-Transmission-Immission (ETI) Concept}

The ETI concept investigates, under conditions similar to natural ones in a laboratory dimension the contaminant mass transport starting from applying contaminant on the top of soil surface until reaching groundwater (Fig. 1). It considers the estimation of emission (E) of the contaminant (i.e., nitrate); the timedependent amount and concentration expressed in a term of 'flux' as volume of contaminant solution per unit area per unit time. The nitrate input flux $J($ in $)$ and the nitrate output flux $J($ out $)$ are given in Equations (1) and (2), respectively.

$$
\begin{aligned}
J(\text { in })= & (C 1 \times V 1-C 2 \times V 2) /(\Delta \mathrm{t} x A) \\
= & (M 1-M 2) /(\Delta \mathrm{t} \times A) \\
= & M(\text { in }) /(\Delta \mathrm{t} \times A)
\end{aligned}
$$

...where $J(i n)$ is the nitrate input flux, $\mathrm{mg} /\left(\mathrm{m}^{2}\right.$ day); $C l$ is the initial concentration of nitrate solution flowing into the cell body, $\mathrm{mg} / \mathrm{L} ; V 1$ is the volume of nitrate solution flowing into the cell body, $\mathrm{L} ; M 1$ is the mass of nitrate entering into the cell body, mg; $C 2$ is the concentration of redundant nitrate solution flowing out of the cell body, $\mathrm{mg} / \mathrm{L} ; \quad V 2$ is the volume of redundant nitrate solution flowing out of the cell body, $\mathrm{L} ; M 2$ is the mass of nitrate flowing out of the cell body, mg; M(in) is the mass of nitrate input flux; i.e., mass of nitrate entering the cell body and equals to $M 1$ minus $M 2, \mathrm{mg} ; \Delta t$ is the time duration starting from the last sampling of solution, day, and A means the effective cross sectional area of the soil sample, $\mathrm{m}^{2}$.

$$
\begin{gathered}
J(\text { out })=(C 4 \times V 4-C 3 \times V 3) /(\Delta \mathrm{t} x A) \\
=M 4 /(\Delta \mathrm{t} \times A) \\
=M(\text { out }) /(\Delta \mathrm{t} \times A)
\end{gathered}
$$

...where $J($ out $)$ is the nitrate output flux, $\mathrm{mg} /\left(\mathrm{m}^{2}\right.$ day); C4 is the concentration of nitrate in mixed solution (nitrate solution and deionized water) flowing out of the cell body, mg/L; V4 is the volume of mixed solution flowing out of the cell body, $\mathrm{L}$; $C 3$ is the concentration 


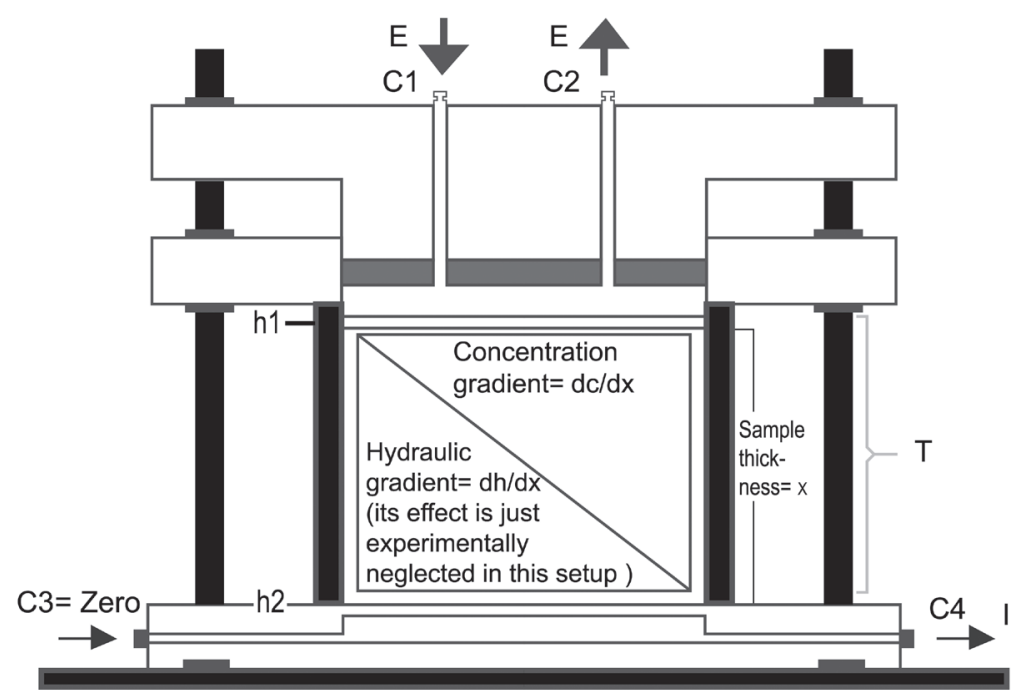

Fig. 1. Scheme of the diffusion cell setup based on the ETI-concept illustrating the main two driving forces of nitrate transport within the soil specimen (diffusion and advection); $C 1, C 2$ and $C 4$ are the nitrate concentrations (mg/L).

of nitrate in deionized water flowing into the cell body, $\mathrm{mg} / \mathrm{L}$, and the value of $C 3$ equals to zero; $V 3$ is the volume of deionized water entering the lower chamber, $\mathrm{L} ; M 4$ is the mass of nitrate in mixed solution flowing out of the cell body mg; and $M($ out $)$ is the mass of nitrate output flux (i.e., mass of nitrate leaving the cell body, $\mathrm{mg})$.

The ODC setup is schematically illustrated in Fig. 1. This technique was separately used for each different soil sample. The sum of differences between the $M$ (in) and M(out) results in the mass of sorbed nitrate, $M$ (sorb). The $M$ (sorb) was mathematically calculated based on the mass balance concept as given in Equation (3). Alternatively, the XACT software was used to obtain the area enclosed under the curves of $J($ in) and $J($ out $)$ as another option to calculate the sorbed amount of nitrate. Using this software, the retarded amounts of nitrate of the soil samples by diffusion and simulated advection were calculated by plotting the results of analyzed mass balance samples from the ODC

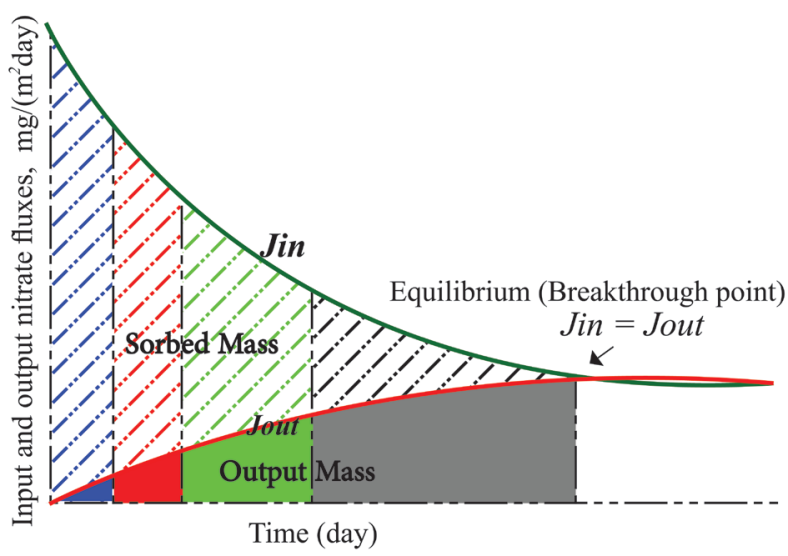

Fig. 2. Mass balance of soil samples. setup by Spectrophotometer (Model 7315, manufactured by Jenway, Germany) and Darcy Law Equation, respectively, against time (Fig. 2).

$$
\begin{gathered}
\mathrm{M}(\text { sorb })=\mathrm{M}(\text { in })-\mathrm{M}(\text { out })+\Delta \mathrm{M} \\
\sum_{\mathrm{t}=0}^{\mathrm{n}}=\left(C(\text { in }) x V(\text { in })-C(\text { out }) x V(\text { out })+\Delta \mathrm{M}_{n}\right)
\end{gathered}
$$

...where $M$ (sorb) is the mass of sorbed nitrate, mg; $M$ (in) is the mass of nitrate input flux, mg; $M$ (out) is the mass of nitrate output flux, $\mathrm{mg} ; \Delta M$ is the difference between mass of nitrate input flux $M($ in) and mass of nitrate output flux $M$ (out), mg; $C$ (in) is the concentration of nitrate input solution, $\mathrm{mg} / \mathrm{L}$; $V$ (in) is the volume of nitrate input solution, $\mathrm{L} ; C$ (out) is the concentration of nitrate output solution, $\mathrm{mg} / \mathrm{L} ; V($ out $)$ is the volume of nitrate output solution, $\mathrm{L}$; and $t$ is the time duration of starting the experiment from 0 until $n$, day.

In a second step, the transmission (T) is evaluated as the pollutant transport through the unsaturated zone into the groundwater. The transport mechanisms of diffusion and retardation potential of the transition zone are considered. The immission (I) into the groundwater can be estimated by the amount and concentration of nitrate input. The amount of nitrate contaminant transported by infiltration into the groundwater can be estimated for every hydrological year using the hydrological parameters. The amount of nitrogen fertilizers applied to the soil also plays a significant role in the range of intensity and widespread groundwater contamination [23].

\section{Setup of the Optimized Diffusion Cell}

In the ODC setup, undisturbed soil specimens of $1 \mathrm{~cm}$ thickness with concentration gradient of the 


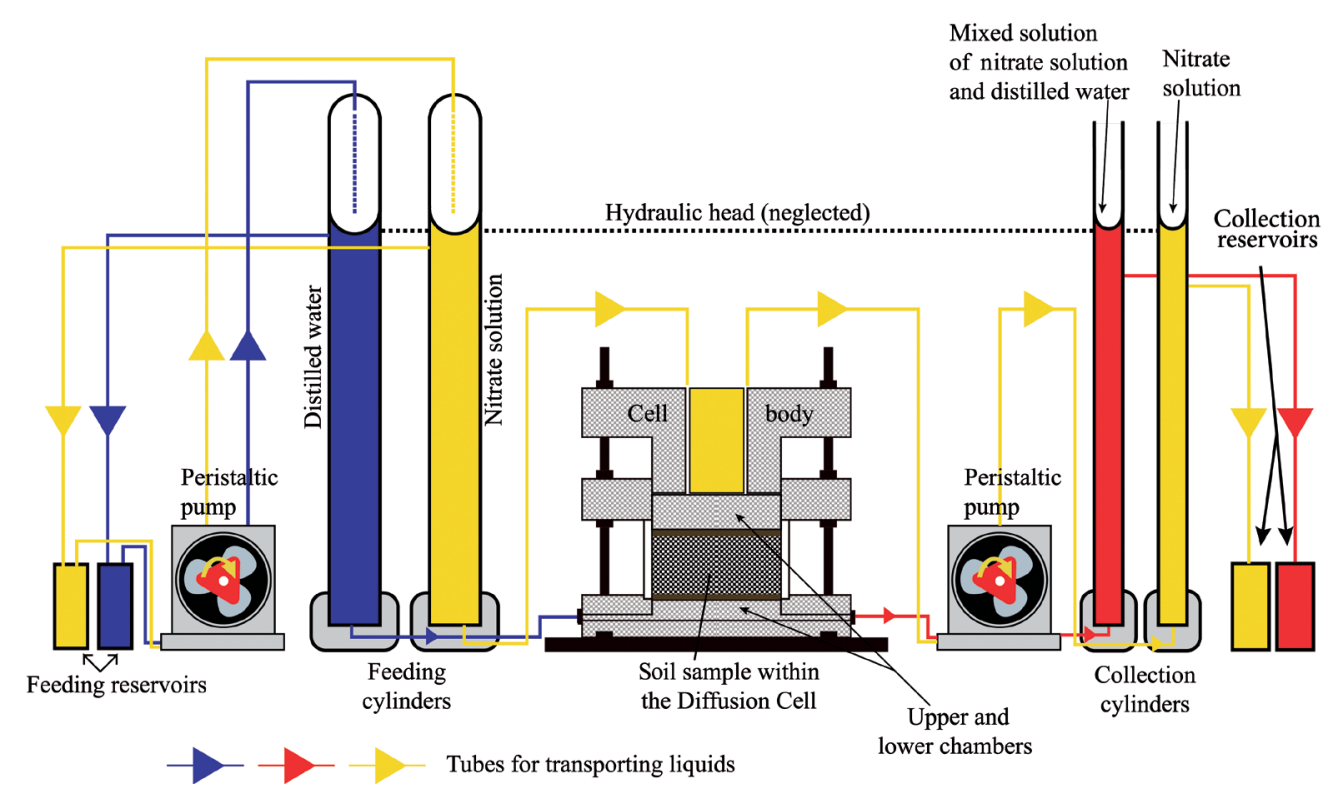

Fig. 3. Scheme of one single optimized diffusion cell setup.

tested contaminant similar to in situ conditions were considered. Thickness of $1 \mathrm{~cm}$ was installed to reduce the time of the experiment. The concentrations of applied nitrate solutions in each ODC were 25, 100 and $250 \mathrm{mg} / \mathrm{L}$. These concentrations were chosen based on the amounts of added fertilizers in the research area of Nettetal/Schwalmtal in Germany. Furthermore, the three nitrate concentrations were chosen in order to obtain adequate data to delineate the curves of sorption isotherm for soil classes and nitrate concentrations. The cell body of the ODC setup, which is shown in Fig. 3, was manufactured at the Department of Engineering Geology and Hydrogeology at RWTH Aachen University, Germany. An explanation of its basic principle is given as follows: A soil specimen is placed between two chambers, with the top one containing a nitrate solution (C1) and a bottom chamber containing deionized water $(C 3=0)$. During the experiment, solution samples $(C 2$ and $C 4)$ from both chambers are collected and analyzed for nitrate concentration. The initial concentration $(\mathrm{Cl})$ was kept constant during the experiment. Deionized water and nitrate solution from both feeding reservoirs were lifted by a peristaltic pump (IPC-N ISM939D, manufactured by ISMATEC, Germany) to feed the two feeding cylinders connected to the setup of the ODC; one is for receiving the distilled water and the other for the nitrate solution. Since in all cylinders the fluid levels are kept at the same height, no advective flow occurs (hydraulic head is ignored). Both the redundant nitrate solution (flowing out of the cell body through the upper chamber) and the mixed solution (nitrate solution and deionized water flowing out of the cell body through the lower chamber) were raised by another peristaltic pump. Each of them was pumped to the respective collection reservoir (Fig. 3).

\section{Modifications Induced to the Optimized Diffusion Cell in Comparison to the Advection-Diffusion Cell}

In order to modify the structure of the advectiondiffusion cell, the following parameters were considered in the ODC (current setup): Biological contamination was avoided by disinfecting the equipment with $3 \%$ hydrogen peroxide. As a result, no microbial growth was found on the top surfaces of soil slices. In contrast, the growth of microorganisms in soil samples of the advection-diffusion cell caused inhibition of nitrate input and output fluxes to reach the breakthrough point (equilibrium state). This point is compassed when the nitrate input flux, $J(i n)$, and the nitrate output flux, $J($ out $)$, become equal.

Additionally, all cylinders, reservoirs and PVC rings of the ODC, where the soil slice is installed, were covered with aluminum foil to prevent algal growth [24]. Moreover, the temperature was maintained as in situ temperature in order to mimic field conditions. In comparison with the advection-diffusion cell the location of the second peristaltic pump was changed (Fig. 3). This is in order to provide adequate driving force to raise liquids through tubes to the collection cylinders. Moreover, undisturbed soil samples were collected and slices of $1 \mathrm{~cm}$ thickness were prepared by use of a press-out device. Eight undisturbed soil samples were imbedded within the ODCs instead of disturbed soil samples. The natural porosity and various soil properties were established. Many soil properties such as soil class, bulk density, permeability, organic matter and total carbon contents, and mass of the soil specimens were determined. These properties are recommended for interpreting the sorption behavior of soil. 
Furthermore, the soil sample in each of the eight ODCs was continuously used after reaching the breakthrough point for all nitrate concentrations. Thus, the measured sorbed amount of nitrate at $25 \mathrm{mg} / \mathrm{L}$ was added to the sorbed amount of nitrate at $100 \mathrm{mg} / \mathrm{L}$. Similarly, the sorbed amount of nitrate at $25 \mathrm{mg} / \mathrm{L}$ and $100 \mathrm{mg} / \mathrm{L}$ were added to the sorbed amount of nitrate at the concentration of $250 \mathrm{mg} / \mathrm{L}$. This concept corresponds to the main concept of sorption isotherm. It states that the higher the concentration, $t$ he more the sorbed amount of nitrate by dry unit mass of soil.

The most significant amendment in the current setup was switching off the effect of hydraulic head in order to enhance the nitrate sorption property by sandy soil. By switching off the advective flow as an effect of the hydraulic head, nitrate solution was better allowed to react with the soil matrix. In other words, no advective flow was applied in the ODC setup in order to prevent the occurrence of turbulent flow instead of laminar, thus causing underestimation of the sorbed amount of retarded nitrate - especially in the case of sandy silt soil samples. However, in order to compensate for the effect of advection in the nitrate sorption process, the advection parameter, which is soil class dependent, was determined based on performing soil permeability tests by triaxial cell or falling head in a standing pipe (Table 1). The simulated advection parameter is discussed in the next section.

\section{Advection}

The driven force to move the contaminant mass flux due to flow movement is advective transport [25]. However, the advection configuration while composing the ODC was neglected according to Equation 4:

$$
J=v \times C \times n e
$$

...where $J$ refers to the one-dimensional flow of a unit cross-sectional area of the porous media per unit time (Mass flux), $\mathrm{mg} /\left(\mathrm{m}^{2}\right.$ day). It depends on the average linear velocity $(v, \mathrm{~m} / \mathrm{day})$, concentration of solution $(C, \mathrm{mg} / \mathrm{L})$ and the effective porosity of media $\left(n_{e}\right.$, dimensionless fraction between 0 and 1 [26].

In our work, the influence of advection was compensated for through performing hydraulic conductivity tests and considering the concentration parameters of the ODC as given in Equations (5) and (6). The value of hydraulic gradient $(i)$ is assumed to be 1 , and the hydraulic conductivity $(K)$ is determined from the hydraulic conductivity tests for different soil samples either by triaxial cell or falling head in a standing pipe (Table 1).

$$
\begin{gathered}
J(\text { in advection })=K x i x(C 1-C 2) \\
J(\text { out advection })=K x \text { i } x(C 4)
\end{gathered}
$$

Table 1 . Soil classes and saturated hydraulic conductivity values.

\begin{tabular}{|c|c|c|}
\hline $\begin{array}{c}\text { Soil } \\
\text { sample }\end{array}$ & $\begin{array}{c}\text { Soil class* } \\
\text { DIN 18123 and } \\
\text { DIN 14688-2 }\end{array}$ & $\begin{array}{c}\text { Saturated hydraulic } \\
\text { conductivity }(\mathrm{K}), \mathrm{m} / \mathrm{s} \\
\text { DIN 18130-1** or } \\
\text { DIN 18130*** }\end{array}$ \\
\hline S1 & Sandy silt, slight clay & $1.89 \times 10^{-8 * *}$ \\
\hline S2 & Sandy silt, slight clay & $7.83 \times 10^{-8 * *}$ \\
\hline S3 & Silty sand & $4.48 \times 10^{-6} * * *$ \\
\hline S4 & Silty sand, slight gravel & $6.65 \times 10^{-6} * * *$ \\
\hline S5 & Silty sand & $5.06 \times 10^{-6} * * *$ \\
\hline S6 & Silty sand & $2.67 \times 10^{-6 * * * *}$ \\
\hline S7 & Silty sand & $6.66 \times 10^{-6} * * *$ \\
\hline S8 & Silty sand & $1.42 \times 10^{-5 * * *}$ \\
\hline
\end{tabular}

*Applied as a combination between sieving and Hydrometer analyses, DIN: German industry standard; the standard applied test, **Triaxial cell experiment, and $* * *$ Falling head in a standing pipe experiment

...where $J$ (in advection) and J(out advection): Nitrate input and output fluxes by advection, $\mathrm{mg} /\left(\mathrm{m}^{2}\right.$ day, respectively, K: Saturated hydraulic conductivity, $\mathrm{m} / \mathrm{s}$, and $i$ : Hydraulic gradient, dimensionless.

\section{Results and Discussion}

The mass of analyzed soil specimens according to the value of bulk density and the volume of each soil sample was calculated (Table 2). Determining masses of soil specimens leads to estimating sorbed ratios of different soil samples. The visual inspection of S7 indicated the presence of organic matter content, which interpreted the lower value of bulk density [27]. Kumar and Philip [16] confirmed similar trends while conducting studies of soil adsorption. Moreover, the total carbon content of S7 and of other analyzed soil samples was examined. S7 had the highest total carbon content, which directly proves the amount of nitrate sorbed [28, 29]. Carbon content of organic origin represents a forthright index to the organic matter content in soils. Subsequently, the nitrate sorption behavior of soil samples is positively related to the carbon content. The majority of total carbon content in the soil samples is composed only from organic carbon. These basic findings are consistent with studies, i.e., Ndala et al. [3], Remya and Azzam [10] and Rama Krishana and Philip [30], showing that the mobility of nitrate is often related to the active components of organic fraction. Organic carbon refers to organic sources producing carbon as an approximation of the level of once-living or decomposed matter [31].

A common negatively charged ion such as nitrate can be effectively retarded, and as long as nitrate has greater affinity to the soil surface than for existing adsorbed ions, sorption will [32, 33]. Mathematically, 
Table 2. Major properties of soil samples.

\begin{tabular}{|c|c|c|c|c|c|}
\hline \multirow{2}{*}{$\begin{array}{c}\text { Soil } \\
\text { sample }\end{array}$} & \multirow{2}{*}{$\begin{array}{c}\text { Bulk density, } \\
\mathrm{g} / \mathrm{cm}^{3}\end{array}$} & $\begin{array}{c}\text { Volume of sample } \\
\text { (volume of chamber), } \mathrm{cm}^{3}\end{array}$ & $\begin{array}{c}\text { Mass of soil } \\
\text { sample, } \mathrm{kg}\end{array}$ & $\begin{array}{c}\text { Inorganic carbon, } \\
\mathrm{mg} / \mathrm{kg} \text { soil }\end{array}$ & $\begin{array}{c}\text { Organic carbon, } \\
\mathrm{mg} / \mathrm{kg} \text { soil }\end{array}$ \\
\hline $\mathrm{S} 1$ & 1.70 & 76.94 & 0.1312 & 8500 & 3760 \\
\hline $\mathrm{S} 2$ & 1.52 & 76.94 & 0.1169 & 0 & 10750 \\
\hline $\mathrm{S} 3$ & 1.76 & 76.94 & 0.1359 & 0 & 10390 \\
\hline S4 & 1.78 & 76.94 & 0.1368 & 0 & 10770 \\
\hline S5 & 1.63 & 76.94 & 0.1265 & 0 & 12170 \\
\hline S6 & 1.60 & 76.94 & 0.1230 & 0 & 6940 \\
\hline S7 & 0.90 & 76.94 & 0.0694 & 0 & 31490 \\
\hline S8 & 1.47 & 76.94 & 0.1131 & 0 & 7400 \\
\hline
\end{tabular}

the sorption behavior of nitrate anion within the soil sample is illustrated by plotting graphs of nitrate fluxes with respect to time as shown in Fig. 2, or it can be calculated using the mass balance concept according to equation (3). As an example, the sorption behavior of S7 is explained. The difference between the two types of fluxes; the nitrate input and output fluxes, of S7 at the concentration of $100 \mathrm{mg} / \mathrm{L}$ was very high at the beginning of the experiment. The curve of nitrate input flux (the curve where its coordinates refer to values of nitrate flux entering the upper chamber of the ODC versus time) flattened out, reaching the breakthrough point at the $65^{\text {th }}$ day, where it crossed the curve of nitrate output flux (the curve where its coordinates refer to values of nitrate flux flowing out of the lower chamber of the ODC versus time). This curve began to ascend starting from the $1^{\text {st }}$ day until the $53^{\text {rd }}$ day, then flattened out reaching to the $65^{\text {th }}$ day where the breakthrough point happened, similar to results obtained by [34].

Interpreting such a pattern of nitrate input and output fluxes versus time can be similarly explained for all the analyzed soil samples, but with a difference in the sorbed amount of nitrate through time. Moreover, at the equilibrium point the soil specimen cannot sorb more nitrate because it is saturated with nitrate in dependence of the running nitrate concentration [34, 35]. This means that at this point the nitrate input flux will penetrate within the soil specimen without retardation. The reason behind the rapid soaring of nitrate output flux curve is imputed to the high difference of concentration gradients - especially at the starting time of the experiment. Subsequently, retaining nitrate at this time is very high. Once the exchangeable sites on soil surface are filled, nitrate will pass out the setup without retardation. A similar pattern of results was reached by AlJazzar and Al-Qinna [21], showing that the nitrate outflux in different initial concentrations (50, 75 and $100 \mathrm{mg} / \mathrm{l}$ ) increased with time.

For all samples, equilibrium was reached in varied interval times as illustrated in Table 3. Subsequently, the difference between the sorption capacities for the respective soil classes at the different nitrate concentrations was recognizable (Table 4). The required time for S1 to reach its breakthrough points was similar to that of S2. A similarity in sorption behavior of the two samples can be imputed to similar soil textures ('sandy silt, slight clay'). S3, S4, S5, S6 and S8 showed approaching behavior to reach the equilibrium state at the three concentrations. It is noteworthy from the former sample behaviors that the equilibrium conditions occurred much earlier than in the other investigated soil samples. S3, S5, S6 and S8 have the same soil texture (silty sand). Although S4 is classified as 'silty sand, slight gravel,' the percentage of gravel in the soil sample is too small and reaches up to $6 \%$. The former mentioned samples (S3, S4, S5, S6 and S8) have relatively the same content of clay and organic matter in addition to almost similar soil texture, which attributes similar sorption behavior to reach the equilibrium point $[17,36]$.

The silty sand sample (S7) has the highest content of organic matter and is classified as peat, fine humus, which apparently caused the relatively long time to reach the breakthrough point. The higher the content

Table 3. Time required by various soil specimens to reach the breakthrough point for the three nitrate concentrations.

\begin{tabular}{|c|c|c|c|}
\hline \multirow{2}{*}{$\begin{array}{c}\text { Soil } \\
\text { sample }\end{array}$} & \multicolumn{3}{|c|}{$\begin{array}{c}\text { Time required to reach the equilibrium } \\
\text { point according to nitrate concentration, day }\end{array}$} \\
\cline { 2 - 4 } & $25 \mathrm{mg} / \mathrm{L}$ & $100 \mathrm{mg} / \mathrm{L}$ & $250 \mathrm{mg} / \mathrm{L}$ \\
\hline S1 & 40 & 49 & 62 \\
\hline S2 & 42 & 51 & 65 \\
\hline S3 & 27 & 46 & 61 \\
\hline S4 & 26 & 41 & 58 \\
\hline S5 & 22 & 34 & 45 \\
\hline S6 & 21 & 34 & 47 \\
\hline S7 & 47 & 65 & 85 \\
\hline S8 & 17 & 27 & 38 \\
\hline
\end{tabular}


Table 4. Sorbed amount of nitrate for each simulated advection, diffusion and total sorbed amount of nitrate by advection and diffusion.

\begin{tabular}{|c|c|c|c|c|c|c|c|c|}
\hline \multirow{2}{*}{$\begin{array}{c}\text { Soil } \\
\text { sample }\end{array}$} & \multicolumn{3}{|c|}{$\begin{array}{l}\text { Sorbed nitrate by advection at three } \\
\text { concentrations, } \mathrm{mg}\end{array}$} & \multicolumn{3}{|c|}{$\begin{array}{l}\text { Sorbed nitrate by diffusion at } \\
\text { three concentrations, mg }\end{array}$} & \multirow{2}{*}{$\begin{array}{c}\text { Total sorbed } \\
\text { nitrate by } \\
\text { advection and } \\
\text { diffusion, mg }\end{array}$} & \multirow{2}{*}{$\begin{array}{l}\text { Total sorbed nitrate } \\
\text { by advection and } \\
\text { diffusion/ total } \\
\text { nitrate mass input, \% }\end{array}$} \\
\hline & $25 \mathrm{mg} / \mathrm{L}$ & $100 \mathrm{mg} / \mathrm{L}$ & $250 \mathrm{mg} / \mathrm{L}$ & $25 \mathrm{mg} / \mathrm{L}$ & $100 \mathrm{mg} / \mathrm{L}$ & $250 \mathrm{mg} / \mathrm{L}$ & & \\
\hline S1 & 0.00002 & 0.00014 & 0.0006 & 19.69 & 140.63 & 635.890 & 796.210 & 36.97 \\
\hline S2 & 0.00001 & 0.00008 & 0.0003 & 20.57 & 139.76 & 621.480 & 781.810 & 32.86 \\
\hline $\mathrm{S} 3$ & 0.00050 & 0.00300 & 0.0098 & 13.11 & 80.460 & 433.120 & 526.700 & 26.12 \\
\hline S4 & 0.00070 & 0.00450 & 0.0144 & 13.56 & 81.230 & 375.810 & 470.620 & 23.90 \\
\hline S5 & 0.00040 & 0.00310 & 0.0110 & 10.27 & 72.160 & 314.850 & 397.290 & 24.96 \\
\hline S6 & 0.00020 & 0.00200 & 0.0054 & 10.51 & 80.990 & 316.430 & 407.940 & 24.32 \\
\hline S7 & 0.00090 & 0.00700 & 0.0250 & 22.48 & 170.60 & 1063.31 & 1256.42 & 47.50 \\
\hline S8 & 0.00088 & 0.00640 & 0.0220 & 8.370 & 55.440 & 201.140 & 264.980 & 20.51 \\
\hline
\end{tabular}

of organic matter, the higher the soil ability to sorb nitrate [37]. Organic matters have large specific surface and high porosity with various chemically reactive functional groups in the pore fluid [38]. Hence they pose high sorption capacity. In this case, the time to reach the breakthrough point (equilibrium state) is relatively long (Table 3).

In a real field situation, the sorption duration would be longer if there is any redox reaction [39]. As this would diminish the nitrate concentration allowing for longer time of sorption until nitrate reaches the groundwater table [40-42]. In the current research, the reduced species of nitrogen were checked and we found no evidence for nitrate reduction. This could be attributed to the disinfection process that has been performed on the equipment used. This result is consistent with what was found in a previous study [21] that reported that if no biological inhibitor was added, then the nitrate flux decreased after a short time of test and that refers to the phenomenon of the formation of a microbial film that consumes nitrate as a growth media and causes some biological reduction.

The total measured amount of sorbed nitrate by advection and diffusion at the three concentrations relative to the total mass input of nitrate (total mass of nitrate entered the ODC ranged between 20.5-47.5\%; Table 4). The results indicate that the silty sand soil sample (S8) had the lowest value of the sorption capacity for the three different nitrate concentrations, whereas the silty sand sample (S7) showed the highest sorption capacity at the same concentrations. This outcome agrees with the literature in that the more sandy the soil, the lower the retardation factor and the sorption capacity [43].

Moreover, the corresponding amounts of sorbed nitrate vary depending on the selected nitrate concentration [44]. With increasing concentrations of nitrate solution, the ability of sorption of soil increases. This can be assigned for the sorption isotherm theory, which states that the higher the adsorbate (nitrate) concentration, the more the adsorbent's (soil specimen) sorption capacity [45]. The available sites for sorption on soil surface vary from the easiest sites for utilizing adsorbate to react and combine with it at low concentrations to all sites at higher concentrations, and also the less easy ones [46]. Furthermore, a higher concentration of nitrate solution entering the soil specimen in the ODC does not necessarily mean that soil specimens will spend less time to reach equilibrium state [34, 47], hence the sorbed amount of nitrate is higher; the enclosed area between the two curves is bigger. This finding is directly in line with what is stated by Aljazzar and A1-Qinna [21], who named the plotted area between the two nitrate fluxes as a confined area representing the amount of nitrate adsorbed within the soil sample and thus indicating nitrate retardation in each sample.

Substantially, the results indicate that the ODC proved to have a premium ability to obtain the amount of sorbed nitrate by various soil samples at different nitrate concentrations determined regarding the inspected contamination levels in situ. The results also point out that diffusion had more effect than simulated advection to retard the greatest amount of nitrate that passed through the soil samples. However, the contribution of nitrate sorption in the advective transport mechanism was much lower than that by diffusion. The sorbed amounts of nitrate by advection for all soil samples did not exceed $1 \%$ of the total sorbed amount of nitrate. This finding might be due to: (1) larger distance to surface of soil particle that can act on nitrate, (2) less contact time with soil particles due to high flow velocity and (3) the flow by advection occurs mainly in the big pores [48], while diffusion in all pores also the very small ones [17].

Furthermore, the results of the current research reveal that advection would not have a severe action in moving nitrate in a sharp concentration (Table 4) as it was not the only parameter influencing the process of nitrate transport. Overall, these findings are in agreement to stated assumptions by Sperelakis [46]. 
The first one 'solute can move with slower velocity than the average linear water velocity (responsible for advective solute transport) if sorption is involved,' The second one 'if advection is the only process affecting the transport of a solute in a homogeneous porous medium, the result would be that the solute would move in the form of distinct, sharp concentration front through the groundwater medium' [46]. These two assumptions assert the low effect of advective transport to sorb nitrate compared to that by diffusion.

A high, environmental and practical significance of the results of mass balance analyses of the ODC is found, as these results can be utilized in further research to test the sorption behavior and the sorption isotherm types of soil samples. Consequently, determining the capacity of a specific soil to diminish contaminant transport is possible. This can be accomplished by recognizing the sorption behavior of soil by applying the ETI concept using the ODC. Furthermore, soil sorption capacity can be timely and quantitatively determined through realizing experimentally the amount of contaminant flux required for the soil sample to be completely saturated. Practically, this is the case at which the soil sample cannot retain more contaminant flux but acts just as a transport media within the unsaturated zone into groundwater [49]. Subsequently, quantification of groundwater or soil vulnerability maps indices of a contaminant (specific vulnerability), using the mass balance analysis restricted by time, are also now being possible. Moreover, ODC examines sorption capacity to other specific contaminants such as nickel (Ni), copper $(\mathrm{Cu})$, zinc $(\mathrm{Zn})$ and lead $(\mathrm{Pb})$ because they can be washed off the root zone very easily and end up in the groundwater together with the percolation water [50, 51]. The results confirm that the ODC is a successful and promising scientifically based methodology and practical procedure for prognosis of contamination input into groundwater quantitatively during time. It can act affectively to inspect the sorption behavior of a specific parameter such as nitrate, and consequently assess the impact of its sources as agriculture, irrigation or even possible influence of human and animal waste, estimate the specific vulnerability caused by nitrate transport into groundwater and consequently control sources of contamination. The only limitation of this study, however, is the long duration of the test. Therefore, it was decided that soil sample thickness should be conducted small of $1 \mathrm{~cm}$ to keep the test duration as short as possible.

\section{Conclusions}

The new experimental technique in this research of ODC was developed to mimic contaminant mass transport into groundwater based on the concept of complementary diffusion capacity. This concept represents continuous permeation of higher concentration of nitrate solution within the soil specimen even after reaching the breakthrough point at the lower concentration of nitrate solution. Subsequently, the mass of fluid diffusion was proportional to the concentration gradient, and the ability of soil sorption increased with increasing concentration of nitrate solution according to the sorption isotherm theory. Moreover, determining the influence of hydraulic head has been successfully compensated by applying triaxial cell and falling head in a standing pipe test instead of embedding it in the ODC setup. Consequently, underestimating values of sorbed amount of nitrates especially in case of silty sand and sandy silt soil samples, attributed to short detention time spent within the sandy soil medium of high percentage of interconnected pore space, was prevented.

\section{Acknowledgements}

The authors gratefully acknowledge the Department of Engineering Geology and Hydrogeology (LIH) at RWTH Aachen University, Germany, for supporting the field and laboratory work.

\section{Conflict of Interest}

The authors declare no conflict of interest.

\section{References}

1. LI Z. Use of surfactant modified zeolite as fertilizer carriers to control nitrate release. Microporous Mesoporous Mater. 61 (1-3), 181, 2003.

2. MCLAY C.D.A., DRAGTEN R., SPARLING G., SELVARAJAH N. Predicting groundwater nitrate concentration in a region of mixed agricultural land use: A comparison of three approaches. Environ. Pollut. 115 (2), 191, 2001.

3. NDALA S.M., SCHOLES M.C., FEY M.V. Soil properties and processes driving the leaching of nitrate in the forested catchments of the eastern escarpment of South Africa. Forest Ecol. Manag. 236 (2-3), 142, 2006.

4. LEVY J., CHESTERS G., GUSTAFSONS D.P., READ H.W. Assessing aquifer susceptibility to and severity of atrazine contamination at field site in south-central Wisconsin, USA. Hydrogeol. J. 6, 489, 1998.

5. MARTINEZ-VILLEGAS N., FLORES-VELEZ L.M., DOMINGUEZ O. Sorption of lead in soil as a function of pH: A study case in Mexico. Chemosphere. 57 (10), 1537, 2004.

6. QAFOKU N.P., SUMNER M.E. Adsorption and desorption of indifferent ions in variable charge subsoils: The possible effect of particle interaction on the counter-ion charge density. Soil Sci. Soc. Am. J. 66, 1231, 2002.

7. EICK M.J., BRADY W.D., LYNCH C.K. Charge properties and nitrate adsorption of some acid south-eastern soils. J. Environ. Qual. 28 (1), 138, 1999.

8. FLINT C.M., HARRISON R.B., STRAHM B.D., ADAMS A.B. Nitrogen leaching from Douglas-fir forests after urea fertilization. J. Environ. Qual. 37 (5), 1781, 2008. 
9. KATOU H., CLOThIER B.E., GREEN S.R. Anion transport involving competitive adsorption during transient water flow in an andisol. Soil Sci. Soc. Am. J. 60 (5), 1368, 1996.

10. REMYA N., AZZAM R. Influence of organic matter and solute concentration on nitrate sorption in batch and diffusion-cell experiments. Bioresour. Technol. 102 (9), 5283,2011

11. CAHN M.D., BOULDIN D.R., CRAVO M.S. Nitrate sorption in the profile of an acid soil. Plant Soil. 143 (2), 179, 1992.

12. OZTURK N., BEKTAS T.E. Nitrate removal from aqueous solution by adsorption onto various materials. J. Hazard. Mater. 112 (1-2), 155, 2004.

13. AZZAM R., LAMBARKI M. Evaluation concept and testing method for heavy metal contaminant transport in the underground. Proceedings of the First EurEnGeo IAEG Conference, Belgium. 316, 2004.

14. SHACKELFORD C.D., DANIEL D.E., LILJESTAND M. Diffusion of inorganic chemical species in compacted clay soil. J. Contam. Hydrol. 4, 241, 1989.

15. MARAQA M.A. Prediction of mass-transfer coefficient for solute transport in porous media. J. Contam. Hydrol. 53 (1-2), 153, 2001.

16. KUMAR M., PHILIP L. Adsorption and desorption characteristics of hydrophobic pesticide endosulfan in four Indian soils. Chemosphere. 62 (7), 1064, 2006.

17. LEE M.J., HWANG S.I., RO H.M. Interpreting the effect of soil texture on transport and removal of nitrate- $\mathrm{N}$ in saline coastal tidal flats under steady-state flow condition. Cont. Shelf Res. 84, 35, 2014.

18. PRADO B., DUWIG C., ETCHEVERS J., GAUDET J.P., VAUCLIN M. Nitrate fate in a Mexican andosol: Is it affected by preferential flow? Agric. Water Manage. 98 (9), 1441, 2011.

19. AZZAM R. Stofftransportprozesse in natürlichen Dichtungsstoffen unter Berücksichtigung der Verdichtbarkeit sowie des Einflusses strukturverändernder Chemikalien auf die Materialeigenschaften. Mitteilungen zur Ingenieurgeologie und Hydrogeologie, RWTH Aachen University. 49, 87, 1993.

20. LAMBARKI M. Entwicklung eines naturnahen Bewertungsverfahrens für die Gefährdungsabschätzung von Altlastverdachtsflächen und Verwertungsmaterialien - ein Beitrag zum Grundwasserschutz. Mitteilungen zur Ingenieurgeologie und Hydrogeologie, RWTH Aachen University. 93, 21, 2006.

21. ALJAZZAR T., AL-QINNA M. Assessment of nitrate transport parameters using the Advection-Diffusion Cell. Environ. Sci. Pollut. Res. Int. 23 (22), 23145, 2016.

22. ALJAZZAR T. Adjustment of DRASTIC vulnerability index to assess groundwater vulnerability for nitrate pollution using the advection diffusion cell. Dissertation, RWTH Aachen University. 23, 2010.

23. JOHNSON R.L., PALMER C.D., FISH W. Subsurface chemical processes: III Transport and Fate of Contaminants in the Subsurface. U.S. Environmental Protection Agency, Center for Environmental Research Information, Cincinnati, $\mathrm{OH}$, and Robert S. Kerr Environmental Research Laboratory, Ada, OK, EPA/ 625/4-89/019, U.S. 1989.

24. AL-QASMI M., RAUT N., TALEBI S., AL-RAJHI S., AL-BARWANI T. A review of effect of light on microalgae growth. Proceedings of the World Congress on Engineering, U.K. 1, 2012.
25. BUZEK F., KADLECOVA R., JACKOVA I., LNENIKOVA Z. Nitrate transport in the unsaturated zone: A case study of the riverbank filtration system Karany, Czech Republic. Hydrol. Processes 26 (5), 645, 2012.

26. SCHULZE-MAKUCH D., CHERKAUER D.S. Variations in hydraulic conductivity with scale of measurement during aquifer tests in heterogeneous, porous, carbonate rocks. Hydrogeol. J. 6 (2), 209, 1998.

27. SOLLINS P., GREGG J.W. Soil organic matter accumulation in relation to changing soil volume, mass, and structure: Concepts and calculations. Geoderma. 301, 60, 2017.

28. SCHWANTES D., GONCALVES A.C., SCHONS D.C., VEIGA T.G., DIEL R.C., SCHWANTES V. Nitrate adsorption using sugar cane bagasse physicochemically changed. Journal of Agriculture and Environmental Sciences. 4 (1), 51, 2015.

29. NOR N.M., LAU C.L., LEE K.T., MOHAMED A.R. Synthesis of activated carbon from lignocellulosic biomass and its applications in air pollution control-A review. J. Environ. Chem. Eng. 1 (4), 658, 2013.

30. RAMA KRISHNA K., PHILIP L. Adsorption and desorption characteristics of lindane, carbofuran and methyl parathion on various Indian soils. J. Hazard. Mater. 160 (2-3), 559, 2008.

31. NIE X., LI Z., HUANG J., LIU L., XIAO H., LIU C., ZENG G. Thermal stability of organic carbon in soil aggregates as affected by soil erosion and deposition. Soil Tillage Res. 175, 82, 2018.

32. FEDER F., BOCHU V., FINDELING A., DOELSCH E. Repeated pig manure applications modify nitrate and chloride competition and fluxes in a Nitisol. Sci. Total Environ. 511, 241, 2015.

33. CHINTALA R., MOLLINEDO J., SCHUMACHER T.E., PAPIERNIK S.K., MALO D.D., CLAY D.E., KUMAR S., GULBRANDSON D.W. Nitrate sorption and desorption in biochars from fast pyrolysis. Microporous and Mesoporous Mater. 179, 250, 2013.

34. HAMDI W., GAMAOUN F., PELSTER D.E., SEFFEN M. Nitrate sorption in an agricultural soil profile. Appl. Environ. Soil Sci. 2013, 1, 2013.

35. MOHSENIPOUR M., SHAHID S., EBRAHIMI K. Nitrate adsorption on clay kaolin: Batch tests. Journal of Chemistry. 2015, 1, 2015.

36. KOOKANA R.S., AHMAD R., FARENHORST A. Sorption of pesticides and its dependence on soil properties: Chemometrics approach for estimating sorption. ACS Symposium Series; 1174, Chapter 12, 221, 2014.

37. YUAN C., MOSLEY L.M., FITZPATRICK R., MARSCHNER P. Amount of organic matter required to induce sulfate reduction in sulfuric material after re-flooding is affected by soil nitrate concentration. J. Environ. Manage. 151, 439, 2015.

38. LEHMANN J., JOSEPH S. (EDs.). Biochar for environmental management: Science, technology and implementation. Routledge, 2015.

39. CHIEN S.C., CHEN S., HUANG K. Arsenic of adsorption characteristics in Taiwan soils. Journal of Applied Science and Engineering. 18 (4), 323, 2015.

40. FALAGAS M.E., THOMAIDIS P.C., KOTSANTIS I.K., SGOUROS K., SAMONIS G., KARAGEORGOPOULOS D.E. Airborne hydrogen peroxide for disinfection of the hospital environment and infection control: A systematic review. Journal of Hospital Infection. 78 (3), 171, 2011. 
41. LOO A.E., HALLIWELL B. Effects of hydrogen peroxide in a keratinocyte-fibroblast co-culture model of wound healing. Biochem. Biophys. Res. Commun. 423 (2), 255, 2012.

42. VIJAYAKUMAR R., KANNAN V.V., SANDLE T., MANOHARAN C. In vitro antifungal efficacy of biguanides and quaternary ammonium compounds against cleanroom fungal isolates. PDA J. Pharm. Sci. Technol. 66 (3), 237, 2012.

43. BLICHER-MATHIESEN G., ANDERSEN H.E., LARSEN S.E. Nitrogen field balances and suction cup-measured $\mathrm{N}$ leaching in Danish catchments. Agric. Ecosyst. Environ. 196, 72, 2014.

44. QAFOKU N.P., SUMNER M.E., RADCLIFFE D.E. Anion transport in columns of variable charge subsoils: Nitrate and chloride. J. Environ. Qual. 29 (2), 484, 2000.

45. FETTER C.W. Contaminant hydrogeology. Second edition, Upper Saddle River, N.J., Prentice Hall, U.S., 27, 1999.

46. SPERELAKIS N. Cell physiology sourcebook: Essentials of membrane biophysics. Third edition, Academic Press, Elsevier, 448, 2012.

47. ZIARANI A.S., AGUILERA R., CLARKSON C.R. Investigating the effect of sorption time on coalbed methane recovery through numerical simulation. Fuel. 90 (7), 2429, 2011.
48. GAO H., MATYKA M., LIU B., KHALILI A., KOSTKA J.E., COLLINS G., JANSEN S., HOLTAPPELS M., JENSEN M.M., BADEWIEN T.H., BECK M., GRUNDWALD M., DE BEER D., LAVIK G., KUYPERS M.M.M. Intensive and extensive nitrogen loss from intertidal permeable sediments of the Wadden Sea. Limnol. Oceanogr. 57 (1), 185, 2012.

49. KLEINMAN P.J.A. The persistent environmental relevance of soil phosphorus sorption saturation. Curr. Pollut. Rep. 3 (2), 141, 2017.

50. REMOUNDAKI E., VASILEIOU E., PHILIPPOU A., PERRAKI M., KOUSI P., HATZIKIOSEYIAN A., STAMATIS G. Groundwater deterioration: The simultaneous effects of intense agricultural activity and heavy metals in soil. Proceedings of the Second EWaS 2016: International Conference on Efficient \& Sustainable Water Systems Management toward Worth Living Development, Procedia Eng. 162, 545, 2016.

51. KELEPERTZIS E., GALANOS E., MITSIS I. Origin, mineral speciation and geochemical baseline mapping of $\mathrm{Ni}$ and $\mathrm{Cr}$ in agricultural topsoils of Thiva Valley (central Greece). J. Geochem. Explor. 125, 56, 2013. 
